\title{
ANALISIS KEMAMPUAN PEMECAHAN MASALAH DAN PENALARAN MATEMATIK SERTA SELF-EFFICACY SISWA SMA
}

\author{
Siti Zakiyah ${ }^{1}$, Syifa Halawatul Imania ${ }^{2}$, Gustiani Rahayu ${ }^{3}$, Wahyu Hidayat ${ }^{4}$ \\ 1,2,3,4Program Studi Pendidikan Matematika IKIP Siliwangi, Jl. Terusan Jenderal Sudirman \\ ${ }^{1}$ zakiyahsugandi@gmail.com, ${ }^{2}$ syfhalawatul@gmail.com, ${ }^{3}$ gustianirahayu17@gmail.com
}

\begin{abstract}
The aims of this research are to know about mathematical problem-solving ability student of senior hig $\mathrm{h}$ school towards trigonometry material, mathematical reasoning ability student of senior high school t owards the statistical material, and self-efficacy ability in mathematics learning students of a senior hig $\mathrm{h}$ school. The research used descriptive qualitative research, and the research object is XI IPA of senio $r$ high school. The chosen students are students who have learned about trigonometry and statistic. The chosen students who become sample are 30 students. In this research, the technic used tests, with the $\mathrm{i}$ nstruments used are question and questionnaire. The test consists of 5 question about mathematics pro blem-solving, 5 question of mathematical reasoning, and 40 questionnaires of self-efficacy ability. Acc ording to the results of our research, it can be concluded that the students' ability in problem-solving an $\mathrm{d}$ reasoning mathematics is low, while students' ability in self-efficacy is good. It can be seen that the $\mathrm{s}$ tudents have good self-efficacy ability along with the problem-solving ability and reasoning ability tha $\mathrm{t}$ are still low.
\end{abstract}

Keywords: Mathematical Problem Solving, Mathematical Reasoning, Self-Efficacy

\begin{abstract}
Abstrak
Penelitian ini bertujuan untuk mengetahui kemampuan pemecahan masalah matematik siswa SMA terhadap materi trigonometri dan kemampuan penalaran matematik siswa SMA terhadap materi statistika, serta kemampuan self-efficacy dalam pembelajaran matematika siswa SMA. Bentuk penelitian yang digunakan adalah penelitian deskriptif kualitatif, dengan objek penelitian siswa SMA kelas XI IPA. Siswa yang dipilih adalah siswa yang telah menempuh materi trigonometri dan statistika. Siswa yang dipilih dan dijadikan sampel sebanyak 30 orang siswa. Dalam penelitian ini, teknik yang digunakan adalah uji tes, dengan instrumen yang digunakan adalah soal dan angket, dimana soal terdiri dari 5 butir soal uraian pemecahan masalah matematik dan 5 butir soal penalaran matematik, serta 40 butir pernyataan berbentuk angket, yaitu angket kemampuan self-efficacy. Berdasarkan hasil penelitian kami, dapat disimpulkan bahwa kemampuan pemecahan masalah dan penalaran matematika siswa rendah, sedangkan untuk kemampuan self-efficacy siswa adalah baik. Hal ini nampak ketidak sesuaian antara kemampuan self-efficacy yang kategori baik dengan kemampuan pemecahan masalah dan penalaran yang masih tergolong rendah.
\end{abstract}

Kata Kunci: Pemecahan Masalah Matematik, Penalaran Matematik, Self-Efficacy

How to cite: Zakiyah, S., Imania, S. H., Rahayu, G., \& Hidayat, W. (2018). Analisis Kemampuan Pemecahan Masalah dan Penalaran Matematik serta Self-Efficacy Siswa SMA. JPMI - Jurnal Pembelajaran Matematika Inovatif, 1 (4), 647-656.

\section{PENDAHULUAN}

Matematika merupakan sebuah ilmu yang sangat penting, karena matematika berperan menjadi dasar bagi pengembangan disiplin ilmu yang lain dalam perkembangan ilmu pengetahuan dan teknologi. Hal tersebut mengakibatkan matematika sangat potensial untuk diajarkan di seluruh jenjang pendidikan mulai dari jenjang pendidikan terrendah sampai dengan jenjang pendidikan 
tertinggi. Matematika dapat membekali siswa dalam mengembangkan kemampuan berpikirnya, seperti berfikir yang logis, kritis, rasional, cermat, sistematis, dan efektif sehingga sangat penting dalam proses terwujudnya kualitas sumber daya manusia yang sesuai dengan tujuan pendidikan nasional. Oleh karena itu, matematika harus dapat dikuasai oleh setiap siswa dengan baik sedini mungkin.

Matematika merupakan disiplin ilmu yang sangat luas, cakupannya yang tidak hanya mengenal angka, pengukuran, operasi bilangan, namun hingga mencakup hal yang kompleks seperti perhitungan mengenai segitiga atau disebut juga trigonometri, dan perhitungan mengenai pengumpulan, pengolahan dan penyajian materi yang disebut statistika.

Selain diharuskan memahami materi dengan baik, siswa juga di haruskan memiliki beberapa kemampuan yang perlu dimiliki. Seperti yang dikemukakan oleh NCTM bahwa terdapat lima kemampuan matematik yang menjadi standar dalam pembelajaran matematika yaitu, kemampuan pemecahan masalah, kemampuan penalaran, kemampuan komunikasi, kemampuan koneksi, dan kemampuan representatif, NCTM (2000). Kami melakukan analisa menenai kemampuan yang dimiliki oleh siswa, yaitu kemampuan pemecahan masalah dan penalaran.

Pemecahan masalah merupakan tahapan belajar paling tinggi yang dikemukakan oleh Gagne, seperti: signal learning, stimulus respons learning, chaining, verbal associating, discrimination learning, concept learning, rule learning, dan problem solving (Hidayat \& Sumarmo, 2013; Hidayat \& Sariningsih, 2018; Wahyu, 2014). Pantas apabila NTCM (2000) mengemukakan bahwa pemecahan masalah adalah jantungnya matematika. Keberadaan pemecahan masalah yang menghantarkan pemikiran manusia menjadi kompleks, tidak hanya dalam penerapannya dalam ilmu matematika tetapi juga dalam kehidupan sehari-hari lainnya. Sejalan dengan pendapat Ruseffendi (2006) yang mengemukakan bahwa, pemecahan masalah sangatlah penting, tidak hanya bagi disiplin ilmu matematika saja, tetapi juga bagi yang akan menerapkannya dalam bidang studi lain serta penerapan dalam kehidupan sehari-hari lainnya. Polya mengemukakan bahwa, terdapat 4 tahapan dalam memecahkan masalah yaitu: (1) memahami masalah; (2) menyusun rencana penyelesaian; (3) melaksanakan rencana penyelesaian; dan (4) melakukan pengecekan kembali.

Sedangkan keamampuan penalaran adalah proses berpikir untuk menentukan apakah sebuah argumen matematika benar atau salah dan juga dipakai untuk membangun suatu argumen matematika baru, (Anisah, Zulkardi, \& Darmawijoyo, 2013). Penalaran merupakan proses mencari kebenaran berdasarkan fakta atau prinsip. Adapun aktivitas yang tercakup di dalam kegiatan penalaran matematis meliputi: menarik kesimpulan logis; menggunakan penjelasan dengan menggunakan model, fakta, sifat-sifat, dan hubungan; memperkirakan jawaban dan proses solusi; menggunakan pola dan hubungan; untuk menganalisis situasi matematik, menarik analogi dan generalisasi; menyusun dan menguji konjektur; memberikan contoh penyangkal (counter example); mengikuti aturan inferensi; memeriksa validitas argumen; menyusun argumen yang valid; menyusun pembuktian langsung, tak langsung dan menggunakan induksi matematik (Hermawan \& Hidayat, 2018; Hidayat, 2017; Hidayat \& Prabawanto; 2018; Isnaeni, Fajriyah, Risky, Purwasih, \& Hidayat, 2018; Sholihat, Hidayat, \& Rohaeti, 2018; Yusdiana \& Hidayat, 2018).

Self-efficacy merupakan kontributor penting untuk mencapai suatu prestasi, apapun kemampuan yang mendasarinya, (Pudjiastuti,2012). Self-efficacy sangat menentukan usaha seseorang untuk mencoba mengatasi situasi yang sulit. Selain itu self-efficacy akan menentukan 
jenis perilaku, seberapa keras usaha yang dilakukan untuk mengatasi persoalan atau menyelesaikan tugas dan berapa lama ia akan berhadapan dengan hambatan-hambatan yang tidak diinginkan (Rahmi, Nadia, Hasibah, \& Hidayat, 2017).

Indikator yang digunakan dalam penelitian kemampuan self-efficacy ini adalah, yakin akan keberhasilah sirinya, mampu mengatasi masalah yang dihadapi, berani menghasapi tantangan, menyadari kekuatan dan kelemahan sendiri, menunjukkan kemampuan berkomunikasi dan beradaptasi, pandangan terhadap pelajaran dan pembelajaran matematika, dan tangguh atau tidak mudah menyerah.

\section{METODE}

Penelitian ini merupakan penelitian deskriptif kualitatif, yaitu penelitian yang bertujuan untuk menggambarkan secara utuh dan mendalam tentang realita sosial dan berbagai fenomena yang terjadi di masyarakat yang menjadi subjek penelitian sehingga tergambarkan ciri, karakter, sifat, dan model dari fenomena tersebut (Sanjaya,2013). Sampel yang digunakan dalam penelitian ini adalah siswa SMA kelas XI-IPA yang dilaksanakan pada tanggal 22 November 2017. Siswa yang dipilih adalah siswa yang telah mempelajari materi trigonometri dan statistika. Siswa yang dipilih dan dijadikan sampel sebanyak 30 orang. Dengan sampel yang dipilih adalah sampel yang berkemampuan matematik tinggi, sedang dan rendah dilihat dari prestasi akademiknya. Dalam penelitian ini, teknik yang digunakan adalah uji tes yang diberikan satu kali, dengan instrumen yang digunakan adalah soal dan angket, dimana soal terdiri dari 5 butir soal uraian pemecahan masalah matematik dan 5 butir soal penalaran matematik, serta 40 butir pernyataan tertutup berbentuk angket, yaitu angket kemampuan selfefficacy, dengan skala yang digunakan adalah skala Likert yang dimodifikasi, yang terdiri dari pilihan, Sangat Setuju (SS), Setuju (S), Tidak Setuju (TS), Sangat Tidak Setuju (STS). Sedangkan kriteria klasifikasi presentase dalam penilaian ini disajikan pada tabel 1.

Tabel 1. Kriteria Klasifikasi Presentase yang Digunakan dalam Penelitian

\begin{tabular}{lll}
\hline Kriteria (\%) & & Klasifikasi \\
\hline & $0 \leq N \leq 20$ & Sangat Rendah \\
$20<N \leq 40$ & Rendah \\
$40<N \leq 60$ & Cukup \\
$60<N \leq 80$ & Baik \\
$80<N \leq 100$ & Sangat Baik \\
\hline
\end{tabular}

(Riduan,2007:87)

Adapun soal-soal yang digunakan dalam penelitian ini adalah sebagai berikut:

Soal-soal Kemampuan Pemecahan Masalah Matematik

Soal 1:

Diketahui segitiga tumpul $\mathrm{ABC}\left(\angle A B C>90^{\circ}\right)$ dengan $\mathrm{AD}$ dan $\mathrm{AE}$ membagi sudut $\mathrm{BAC}$ sama besar. Jika panjang segmen garis $\mathrm{BD}, \mathrm{DE}$, dan $\mathrm{EC}$ berturut-turut adalah 2, 3, dan 6 maka tentukan panjang sisi segitiga terpendek $\mathrm{ABC}$.

Soal 2:

Titik E terletak di dalam persegi $\mathrm{ABCD}$ sedemikian sehingga $\mathrm{ABE}$ adalah segitiga sama sisi. Jika panjang $A B=8 \mathrm{~cm}$ dan $\mathrm{F}$ adalah titik potong antara diagonal $\mathrm{BD}$ dengan segmen garis $\mathrm{AE}$, hitunglah luas segitiga $\mathrm{ABF}$. 


\section{Soal 3:}

Di halaman sekolah ditanami beberapa jenis pohon diantaranya Palem, Ketapang, Rambutan dan Sawo. Letak pohon Ketapang dan Rambutan sejajar dengan jarak 5m. Diantara kedua pohon tersebut terletak pohon Sawo dengan jarak 3m dari Ketapang, sedangkan jarak dari Palem ke Sawo tegak lurus terhada jarak dari Ketapang ke Rambutan sehingga jarak Palem ke Ketapang dengan jarak Palem ke Rambutan membentuk sudut $45^{\circ}$. Hitunglah berapa luas daerah yang dapat dipasang pagar antara pohon Palem, Ketapang, dan Rambutan yang membentuk sebuah segitiga.

\section{Soal 4:}

Pada segitiga $\mathrm{ABC}$, garis bagi sudut $\mathrm{A}$ memotong sisi $\mathrm{BC}$ dititik $\mathrm{D}$. Jika $A B=A D=2$ dan $B D=\frac{1}{4}$, tentukan panjang $\mathrm{CD}$.

\section{Soal 5:}

Pada suatu segitiga $\mathrm{ABC}$, sudut $\mathrm{C}$ tiga kali besar sudut $\mathrm{A}$, dan sudut $\mathrm{B}$ dua kali besar sudut Berapakah perbandingan antara panjang $\mathrm{AB}$ dab $\mathrm{BC}$ ?

Soal-soal Kemampuan Penalaran Matematik

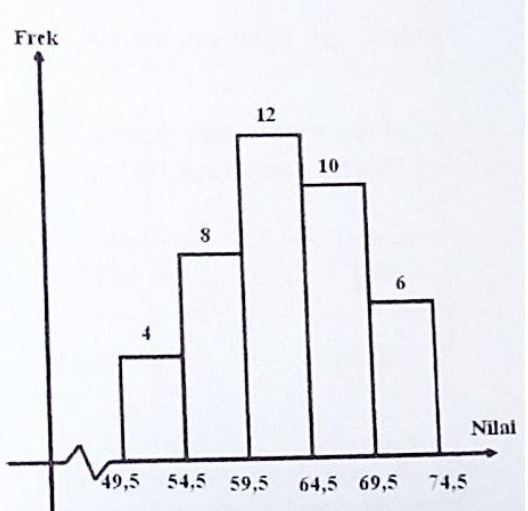

Soal 1:

Perkirakan diselang bagian manakah terdapat median dan rata-rata dari gambar diatas? Jelaskan!

Soal 2:

Sekelompok data tunggal membentuk barisan aritmetika, dengan data ketiga sama dengan 77 dan data ke delapan sama dengan 87. Berapa banyak data untuk nilai rata-rata 82? Dimanakah letak mediannya? Jelaskan jawabanmu!

Soal 3:

Asep lulusan SMA jurusan IPA yang akan mengajukan lamaran kerja pada dua perusahaan yaitu PT. Pupuk Kujang dan PT. Indofood. Di PT. Pupuk Kujang bayaknya lulusan SMA yang diperlukan adalah 48 orang, sedangkan di PT. Indofood 9 orang. Andaikan pelamar yang sudah mendaftar di PT. Pupuk Kujang adalah 840 orang dan PT. Indofood adalah 135 orang. Diperusahaan manakah Asep harus mengajukan lamaran sehingga peluang diterimanya lebih besar? Berikan alasanmu!

\section{Soal 4:}

Sebuah perusahaan membuka lowongan kerja untuk 1 tenaga pembukuan, 1 tenaga operator komputer dan 2 orang tenaga penjualan. Terdapat 25 orang yang mengajukan lamaran terdiri dari 10 laki-laki dan 15 perempuan, tiap pelamar mempunyai kesempatan yang sama untuk mengisi posisi tersebut. 
a). Laki-laki atau wanita yang berpeluang lebih besar untuk mengisi posisi tenaga operator komputer? Jelaskan aturan yang digunakan!

b). Bila ternyata tenaga pembukuan dan tenaga operator di isi oleh perempuan, maka akan dipilih sekaligus dua tenaga penjualan. Manakah yang peluangnya lebih besar, keduanya lakilaki, atau satu laki-laki dan satu perempuan. Aturan apa yang digunakan?

Teknik analisis data yang digunakan dalam penelitian ini adalah analisis kuantitatif-kualitatif. Langkah pertama dalam menganalisis penelitian ini adalah dengan menggunakan teknik kuantitatif dalam mengetahui hasil dan persentase kemampuan pemecahan masalah matematik, penalaran matematik, dan self-efficacy siswa. Langkah selanjutnya adalah dengan menentukan kelasifikasi kemampuan berdasarkan persentasenya.

Selain itu kisi-kisi self-efficacy dalam penelitian ini disajikan dalam Tabel 2.

Tabel 2. Kisi-kisi Angket Self-efficacy

\begin{tabular}{lll}
\hline Indikator & Positif & Negatif \\
\hline Yakin akan keberhasilan dirinya & 4 & 3 \\
Mampu mengatasi masalah yang dihadapi & 4 & 3 \\
Berani menghadapi tantangan & 2 & 3 \\
Menyadari kekuatan dan kelemahan sendiri & 3 & 3 \\
Menunjukan kemampuan berkomunikasi dan beradaptasi & 3 & 3 \\
Pandangan terhadap pelajaran dan pembelajaran matematika & 3 & 3 \\
Tangguh atau tidak mudah menyerah & 1 & 2 \\
\hline Jumlah Pernyataan & 40 & \\
\hline
\end{tabular}

\section{HASIL DAN PEMBAHASAN}

\section{Hasil}

Berikut merupakan rincian hasil tes kemampuan pemecahan masalah dan penalaran matematik serta self efficacy siswa SMA disajikan pada tabel-tabel dibawah ini.

Tabel 3. Hasil Analisis Kemampuan Pemecahan Masalah Berdasarkan Nomor Soal

\begin{tabular}{lll}
\hline Soal & Persentase & Kategori \\
\hline Soal 1 & 33,33 & buruk \\
Soal 2 & 44,44 & cukup \\
Soal 3 & 38,89 & buruk \\
Soal 4 & 16,67 & sangat buruk \\
Soal 5 & 44,44 & cukup \\
\hline Total & 23,7 & buruk \\
\hline
\end{tabular}

Tabel 4. Hasil Analisis Kemampuan Penalaran Berdasarkan Nomor Soal

\begin{tabular}{lll}
\hline Soal & Persentase & Kategori \\
\hline Soal 1 & 54,17 & cukup \\
Soal 2 & 54,17 & cukup \\
Soal 3 & 45,83 & cukup \\
Soal 4 & 25 & buruk \\
Soal 5 & 20,833 & sangat buruk \\
\hline Total & 40 & buruk \\
\hline
\end{tabular}


Tabel 5. Analisis Kemampuan Self-Efficacy Berdasarkan Indikatornya

\begin{tabular}{llll}
\hline Indikator & Banyak Pernyataan & Presentase & Kategori \\
\hline Yakin akan keberhasilan dirinya & 7 & 65,77 & Baik \\
$\begin{array}{l}\text { Mampu mengatasi masalah yang dihadapi } \\
\text { Berani menghadapi tantangan }\end{array}$ & 7 & 63,98 & Baik \\
$\begin{array}{l}\text { Menyadari kekuatan dan kelemahan } \\
\text { sendiri }\end{array}$ & 5 & 74,58 & Baik \\
$\begin{array}{l}\text { Menunjukan kemampuan berkomunikasi } \\
\text { dan beradaptasi }\end{array}$ & 6 & 69,09 & Baik \\
$\begin{array}{l}\text { Pandangan terhadap pelajaran dan } \\
\text { pembelajaran matematika }\end{array}$ & 6 & 78,81 & Baik \\
$\begin{array}{l}\text { Tangguh atau tidak mudah menyerah } \\
\text { Total }\end{array}$ & 3 & 79,86 & Baik \\
\hline
\end{tabular}

\section{Pembahasan}

Analasis mengenai soal nomor satu, dua, dan tiga dalam kemampuan pemecahan masalah ini memiliki kesamaan dalam hasil penilaian, yaitu rata-rata dari siswa hanya mampu menyeselasaikan soal dengan mengungkapkan informasi dan memahami masalah yang diajukan, sedangkan untuk tahap pemilihan strategi atau cara penyelesaian tahap menyelesaikan permasalahan, dan tahap verifikasi hasil sebagian besar dari siswa belum mampu menyelesaikannya secara utuh. Sedangkan untuk soal nomor empat, sebagian dari siswa tidak menjawab soal sedikit pun, adapun menjawab hanya sampai kepada tahap mengungkapkan informasi dan memahami masalah yang diajukan. Untuk soal nomor lima, nampak perbedaan dimana terdapat siswa yang menjawab dengan skor maksimal dan terdapat siswa yang tidak memberikan jawaban.

Tabel 6. Hasil Anaisis Kemampuan Pemecahan Masalah Berdasarkan Tahapannya

\begin{tabular}{llll}
\hline Tahapan Pemecahan Masalah & Jumlah & Persentase & Karakter-istik \\
\hline Memahami masalah & 150 & 83,33 & Sangat Baik \\
Memilih rencana strategi pemecahan masalah & 92,5 & 51,39 & Cukup \\
Menyelesaikan masalah & 67,5 & 37,5 & Rendah \\
Verifikasi dan informasi hasil & 52,5 & 29,17 & Rendah \\
\hline
\end{tabular}

Berdasarkan tabel 6. di atas, dapat kita lihat bahwa persentase kemampuan siswa memecahkan masalah dari tahap awal hingga ke akhir mengalami penurunan. Kemampuan siswa dalam memahami masalah, sudah tergolong sangat tinggi, 83,3\%. Untuk tahap memilih strategi pemecahan masalah tergolong cukup, 51,39\%. Dan untuk tahap menyelesaikan permasalahan masih tergolong rendah, sebesar $37,5 \%$. Sedangkan tahap akhir, yaitu mengecek kembali proses dan hasil yang didapat atau tahap verifikasi memperoleh angka rendah, yaitu 29,17\%. Sejalan dengan penelitian yang dilakukan oleh Ariani, Hartono, Hiltrimartin, (2017) yang mengatakan bahwa kemampuan siswa memahami permasalahan $89,63 \%$, tahap memilih strategi pemecahan masalah $63,7 \%$, tahap menyelesaikan permasalahan $45,56 \%$, dan untuk kemampuan verifikasi tidak sejalan dengan penelitian kami, angka yang dihasilkan sebantar 16, 11\%.

Berdasarkan tabel 3. diatas, dapat kami simpulkan bahwa kemampuan pemecahan masalah matematik siswa sebesar $23,7 \%$ atau tergolong dalam kategori rendah. Kemampuan mereka dalam memahami permasalahan dan menariknya menjadi sesuatu yang diketahui dan ditanyakan sudah baik, namun saat menentukan siasat atau strategi dalam penyelesaian mereka 
masih rendah, untuk menyelesaikan permasalahannya pun mereka masih rendah, sedangkan untuk melakukan verifikasi, dikarenakan mereka telah memahami permasalahan dengan baik jadi sebagian dari mereka telah mengetahui apa yang perlu diverifikasi.

Berdasarkan hasil analisis kemampuan soal penalaran nomor satu, dua, dan tiga hampir memiliki kesamaan dalam penilaiannya. Siswa sudah mampu memahami konsep tetapi belum bisa menjawab dengan tepat seluruhnya. Untuk penyelesaian nomer satu sebagian siswa tidak menyajikan data dalam bentuk tabel frekuensi pada penyelesaian soalnya, sedangkan pada soal nomor dua kebanyakan siswa hanya mencari nilai rata-rata saja dengan penyelesaian yang kurang tepat dan untuk nomer tiga sebagian besar siswa hanya menentukan nilai peluangnya saja berdasarkan logika tetapi masih belum sesuai. Sehingga skor yang didapat setiap siswa pada soal nomer satu, dua, dan tiga belum ada yang maksimal. Untuk anlaisis nomor empat, siswa masih kurang memahami konsep sehingga belum dapat menyelesaikan soal sesuai dengan aturan yang ada dan hanya menjawab sesuai logika yang diketahui tanpa menggunkan rumus, ada juga siswa yang tidak memberikan jawaban. Analisis soal nomer lima siswa hanya memperkirakan banyak susunan pada model 1 dan model 2 tanpa menggunakan perhitungan dan tidak menggunakan aturan yang ada, terdapat siswa yang tidak memberikan jawaban.

Berdasarkan tabel 4. diatas, serta keseluruhan analisis jawaban siswa maka dapat disimpulkan bahwa kemampuan penalaran siswa masih tergolong rendah yaitu sebesar $40 \%$. Siswa belum mampu menyelesaikan semua soal dengan tepat, dan hanya mampu menyelesaikan beberapa soal dengan benar walaupun tidak seluruhnya. Masih banyak cara penyelesaiannya yang tidak sesuai dengan aturan dan ada yang tidak memberikan jawaban dibeberapa point soal. Dengan demikian guru harus mampu mengembangkan kemampuan penalaran siswa pada saat proses pemebelajaran matematika, tetapi kenyataan berdasarkan hasil penelitian dilapangan kemampuan penalaran siswa masih kurang. Hal ini juga sejalan dengan hasil penelitian Riyanto \& Siroj (2014) selama menjadi guru di SMA dan hasil wawancara dengan teman guru bahwa kemampuan penalaran matematik dan prestasi siswa juga masih kurang.

Dari tabel 5. menunjukan hasil dari kemampuan self-efficacy pada siswa SMA dalam pembelajaran matematika yang dinilai berdasarkan indikator-indikatornya. Pada indikator pertama yaitu yakin akan keberhasilan dirinya dengan penilaian $65,77 \%$ tidak sejalan dengan hasil kemampuan pemecahan masalah dan penalaran, dikarenakan terlihat dari hasil penilaian kemampuan pemecahan masalah dan penalaran yang rata-rata hanya mampu manyelasaikan soal sampai pada tahap memahami masalah selain itu masih terdapat siswa yang tidak memberikan respon.

Untuk indikator ke-dua yaitu mampu mengatasi masalah yang dihadapi memiliki hasil penilaian $63,98 \%$. Dalam indikator yang kedua ini tidak sesuai dengan hasil dari penilaian kemampuan pemecahan masalah dan juga kemampuan penalaran, siswa kurang mampu memahami strategi yang akan digunakan dalam mengerjakan soal yang menyebabkan nilai dalam kemamouan pemecahan masalah rendah dan begitu pun pada kemapuan penalaran.

Dalam indikator ke-tiga ialah berani menghadapi tantangan dapat dikatakan sejalan dengan hasil penilaian terhadap kemampuan pemecahan masalah dan juga penalaran. Indikator yang ketiga ini memiliki persentasi nilai $74,58 \%$, dikatakan sejalan ketika diberikan soal siswa berusaha untuk mengerjakan meskipun jawaban siswa masih kurang tepat.

Indikator yang ke-empat mengenai menyadari kekuatan dan kelemahan sendiri pun dapat dikatakan sesuai dengan hasil penilaian kemampuan pemecahan masalah dan penalaran 
matematika, karena siswa mampu mengetahui soal yang menurutnya mampu ia kerjakan dan juga yang tidak dapat ia kerjakan. Dengan begitu indikator ke empat ini sesuai dengan hasil penilaian kemampuan pemecahan masalah dan penalaran yang mempunyai presentase $69,09 \%$.

Sedangkan indikator ke-lima yang menunjukan kemampuan berkomunikasi dan beradaptasi sebesar 78,81\% dapat dikategorikan baik. Selain itu, indikator keenam yang memiliki presentase tertinggi sebesar $79,86 \%$ diantara ketujuh indikator pada Self-efficacy ini tidak dapat dikatakan sesuai ataupun tidak sesuai dengan kemampuan pemecahan masalah dan juga penalaran. Dimana indikator keenam ini yaitu pandangan terhadap pelajaran dan pembelajaran matematika mengenai anggapan siswa bahwa pelajaran dan pembelajaran matematika itu penting. Siswa menganggap jika menyelasaikan soal matematika merupakan saat yang menyenangkan dan menarik, walaupun beberapa siswa masih sering kesulitan saat menyelesaikan soal matematika yang diberikan.

Indikator ketujuh yaitu tangguh atau tidak mudah menyerah adalah indikator terakhir dari kemampuan Self-efficacy. Indikator ketujuh ini juga yang memiliki presentase yeng terendah yaitu $59,72 \%$. Indikator ini pun sesuai dengan hasil penilaian kemampuan pemecahan masalah serta kemampuan penalaran, karena terlihat dari jawaban siswa masih ada yang tidak menjawab atau tidak merespon.

Sehingga dapat disimpulkan bahwa dari keseluruhan indikator kemampuan self-efficacy matematika siswa SMA dikatakan baik. Yang berada di presentase nilai total $71,04 \%$. Kemampuan self-efficacy ini sama seperti penelitian yang dilakukan oleh Sifah (2016) mengemukakan bahwa self-efficacy siswa SMA berada pada kategori tinggi yang berpengaruh terhadap karir secara positif. Namun, hasil tersebut tidak sesuai dengan hasil penilaian kemampuan pemecahan masalah dan penalaran matematika siswa SMA.

\section{KESIMPULAN}

Berdasarkan hasil penelitian dan pembahasan yang kami lakukan bahwa, kemampuan pemecahan masalah matematika siswa SMA adalah rendah, dengan nilai 23,7\%. Adapun, kemampuan penalaran matematika siswa SMA adalah rendah dengan persentase $40 \%$. Serta kemampuan self-efficacy siswa SMA adalah 71,04\% yang berada pada kategori baik.

\section{DAFTAR PUSTAKA}

Anisah, A., Zulkardi, Z., \& Darmawijoyo, D. (2013). Pengembangan Soal Matematika Model PISA pada Konten Quantity Untuk Mengukur Kemampuan Penalaran Matematis Siswa Sekolah Menengah Pertama. Jurnal Pendidikan Matematika, 5 (1).

Ariani, S., Hartono, Y., dan Hiltrimartin, C. (2017). Kemampuan Pemecahan Masalah Siswa Pada Pembelajaran Matematika Menggunakan Strategi Abduktif-Deduktif di SMA Negeri 1 Indralaya Utara. Jurnal Elemen, 3 (1), 25-34.

Effendi, L. A. (2012). Pembelajaran Matematika dengan Metode Penemuan Terbimbing Untuk Meningkatkan Kemampuan Representasi dan Pemecahan Masalah Matematis Siswa SMP. Jurnal Penelitian Pendidikan, 13 (2). 
Hermawan, A. S., \& Hidayat, W. (2018). Meningkatkan Kemampuan Penalaran Matematik Siswa SMP Melalui Pendekatan Penemuan Terbimbing. JPMI (Jurnal Pembelajaran Matematika Inovatif), 1(1), 7-20.

Hidayat, W. (2017). Adversity Quotient dan Penalaran Kreatif Matematis Siswa SMA dalam Pembelajaran Argument Driven Inquiry pada Materi Turunan Fungsi. KALAMATIKA Jurnal Pendidikan Matematika, 2(1), 15-28.

Hidayat, W., \& Prabawanto, S. (2018, January). Improving students' creative mathematical reasoning ability students through adversity quotient and argument driven inquiry learning. In Journal of Physics: Conference Series (Vol. 948, No. 1, p. 012005). IOP Publishing.

Hidayat, W., \& Sumarmo, U. (2013). Kemampuan Komunikasi dan Berpikir Logis Matematika serta Kemandirian Belajar. dalam Jurnal Delta-fi, 2(1).

Hidayat, W., \& Sariningsih, R. (2018). Kemampuan Pemecahan Masalah Matematis dan Adversity Quotient Siswa SMP Melalui Pembelajaran Open Ended. JNPM (Jurnal Nasional Pendidikan Matematika), 2(1), 109-118.

Isnaeni, S., Fajriyah, L., Risky, E. S., Purwasih, R., \& Hidayat, W. (2018). Analisis Kemampuan Penalaran Matematis dan Kemandirian Belajar Siswa SMP pada Materi Persamaan Garis Lurus. Journal of Medives, 2(1), 107-116.

National Council of Teachers of Mathematic (NCTM). (2000). Principle and Standards for School Mathematics. NCTM.

Pudjiastuti, E. (2012). Hubungan "Self Efficacy" dengan Perilaku Mencontek Mahasiswa Psikologi. MIMBAR, Jurnal Sosial dan Pembangunan, 28 (1), 103-111.

Rahmi, S., Nadia, R., Hasibah, B., \& Hidayat, W. (2017). The Relation between Self-Efficacy toward Math with the Math Communication Competence. Infinity Journal, 6(2), 177182.

Riduan. (2007). Dasar-dasar Statistika. Bandung: Alfabeta.

Riyanto, B., \& Siroj, R. A. (2014). Meningkatkan Kemampuan Penalaran dan Prestasi Matematika dengan Pendekatan Konstruktivisme Pada Siswa Sekolah Menengah Atas. Jurnal Pendidikan Matematika, 5 (2).

Ruseffendi, E. T. (2006). Pengajaran Matematika Untuk Meningkatkan CBSA. Bandung: Tarsito.

Sanjaya, W. (2013). Penelitian Pendidikan Jenis, Metode, dan Prosedur. Jakarta: Kencana Prenada Media Group.

Sholihat, N. A. N., Hidayat, W., \& Rohaeti, E. E. (2018). PENGHARGAAN DIRI DAN PENALARAN MATEMATIS SISWA MTS. JPMI (Jurnal Pembelajaran Matematika Inovatif), 1(3). 
Sifah, E. Z. (2016). Pengaruh Efikasi Diri Terhadap Aspirasi Karis Pada Siswa Kelas X SMA Negeri 1 Depok Sleman Yogyakarta. E-journal Bimbingan dan Konseling.

Suherman, E, dkk. (2003). Strategi Pembelajaran Matematika Kontemporer. Bandung: Universitas Pendidikan Indonesia.

Wahyu, H. (2014). The Implementation of MEAs Instruction to Students' Mathematics Problem Solving and Connecting Ability. In Proceeding of International Conference on Research, Implementation and Education of Mathematics and Sciences 2014. Yogyakarta State University.

Yusdiana, B. I., \& Hidayat, W. (2018). ANALISIS KEMAMPUAN PENALARAN MATEMATIS SISWA SMA PADA MATERI LIMIT FUNGSI. JPMI (Jurnal Pembelajaran Matematika Inovatif), 1(3). 